\title{
Screening of drought tolerant foxtail millet (Setaria italica beauv) germplasm
}

\author{
F. Begum,* R. Sultana and A. Nessa
}

\author{
Bangladesh Agricultural Research Institute Joydebpur, Gazipur
}

\begin{abstract}
A field experiment on foxtail millet was laid out under irrigated and rainfed condition to screen semi drought tolerant lines. Parameters studied, like plant height, total dry matter accumulation and yield decrease under rainfed condition as compared to that under irrigated conditioned. It is observed that out of 19 lines, considering plant height stress index, seventeen lines showed tolerance above the test crop (Titas). The lines HYM 11/BSi 427, HYM 12/BSi 467, EM 15/BSi 467 and BSi I showed better tolerance than the test crop when dry matter stress index was considered. Nine lines out of 19 showed better yield stability ratio as compared to test crop (Titas). It is observed that greater the tolerance index, larger is the yield gap between normal and stress condition. Considering all the parameters like PHSI, DMSI , TOL, YS ratio, drought susceptibility index and also the visual observation, the lines BSi-1, EM 15/ BSi 467 and EM 8 /BSi 467 showed better performance than the test crop.
\end{abstract}

Keywords: Millet; Drought; Plant height stress index (PHSI); Dry matter stress index (DMSI); Tolerance index (TOL); Yield stability ratio (YS); Drought susceptibility index (YSI).

\section{Introduction}

Millets refer to a group of small seeded cereals which play an important role in global agriculture and have been growing from ancient times in traditional agricultural system. Millets are better adapted to dry and infertile soils and are drought tolerant and less susceptible to disease and insect pests. These crops are usually grown on light, well-drained soils that are poor in organic matter content without irrigation or chemical fertilizer.

In Bangladesh mainly foxtail millet and proso millet are cultivated and are grown in rabi and kharif seasons in all types of soil as sole or mixed crops with chili, aus rice, sesame, mustard etc. Millets altogether occupy an area of 36,310 acres producing $12,085 \mathrm{M}$. ton of grain with an average grain yield of $865 \mathrm{~kg} / \mathrm{ha}$. (BBS, 2000). The total acreage and production of millets and other minor cereals have declined considerably in recent years. The high population pressure have led to a shortening of fallow periods, which in turn has accelerated the decline in soil fertility and these factors have prompted the expansion of millet into more marginal lands.

Considering the above circumstances, the present investigation was under taken to identify the better drought tolerant lines of foxtail millets compared to the existing variety Titas, so that it can be grown in areas where irrigation water is limited and other cereals cannot be grown successfully. To select drought tolerant lines, study of plant height stress index (Bouslama and Schapangh, 1984), dry matter accumulation stress (Bouslama and Schapangh, 1984), yield stability ratio (Lewis, 1954), Tolerance index (Hossain et al. 1990) and drought susceptibility index (Bouslama and Schapangh, 1984) were done as measures of drought tolerance.

\section{Material and methods}

The experiment was conducted during the rabi season of 2007-2008 at Central Research Station, BARI, Joydebpur. Twenty varieties/lines including Titas (Test crop) were sown under rainfed and irrigated condition. The experiment was laid out in a RCB design with four replications. Fertilizer dose (45-30-20 kg NPK/ha) were given according to standard recommended practices. Total TSP, MP and half of the urea were given as basal dose and the rest half of the urea were given at tillering and panicle initiation stage. The unit plot size was $4 \mathrm{~m} \times 5 \mathrm{~m}$. Two irrigations (at tillering stage and panicle initiation stage) were applied to crops grown under irrigated condition. No irrigation was given to plants grown under rainfed condition. Data on soil moisture (\%) were also recorded (Table III). Plant height, dry matter accumulation and also yield of millet grown under rainfed and irrigated condition were recorded to measure plant height stress index, dry matter stress index ,tolerance index, yield

\footnotetext{
*Corresponding author.
} 
stability ratio and drought susceptibility index .

Formulae used in this work were given below:-

(i) $\mathrm{PHSI}=\frac{\text { Plant height } \text { under } \text { rain fed condition }}{\text { Plant height under irrigated condition }} \times 100$

(ii) $\frac{\text { Total dry matter under rain fed condition }}{\text { Total dry matter under irrigated condition }}$ DMSI $=\times 100$

(iii) Tolerance index $=$ Yield under irrigated condition - Yield under rain fed condition

(iv) Yield stability ratio $\frac{\text { Yield under rain fed condition }}{\text { Yield under irrigated condition }} \times 100$

(v) YSI $=1-\frac{\text { Yield under rain fed condition }}{\text { Yield under irrigated condition }} / \mathrm{D}$ where D is the drought intensity,

$$
\mathrm{D}=\frac{\begin{array}{l}
\text { Mean yield of all the genotypes } \\
\text { under rain fed condition }
\end{array}}{\begin{array}{l}
\text { Mean yield of all the genotypes } \\
\text { under irrigated condition }
\end{array}} \times 100
$$

\section{Results and discussion}

In general, plant height of millet was reduced under rainfed condition as compared to irrigated condition (Table I).It was observed that plant height of all the millet lines / variety is reduced under rainfed condition compared to those grown under irrigated condition (Table I) .The mean plant height increased gradually up to $87.95 \mathrm{~cm}$ in 110 days after emergence under irrigated condition (Table I) and it was reduced to $66.96 \mathrm{~cm}$ when grown under rainfed condition (Table II). In case of the check variety (Titas), the mean plant height

\begin{tabular}{|c|c|c|c|c|c|c|c|}
\hline \multirow[t]{2}{*}{$\begin{array}{l}\text { Sl. } \\
\text { No. }\end{array}$} & \multirow[t]{2}{*}{$\begin{array}{l}\text { Lines/ } \\
\text { varieties }\end{array}$} & \multicolumn{2}{|c|}{$\begin{array}{l}\text { Plant height } \\
\text { (cm) }\end{array}$} & \multicolumn{2}{|c|}{$\begin{array}{l}\text { Dry weight } \\
\text { (mg/plant) }\end{array}$} & \multicolumn{2}{|c|}{$\begin{array}{l}\text { Yield } \\
\text { g/plant }\end{array}$} \\
\hline & & Irrigated & Rain fed & Irrigated & Rain fed & Irrigated & Rain fed \\
\hline 1 & EM-6/BSi-1 & 80.73 & 66.20 & 3583 & 1250 & 8.23 & 3.27 \\
\hline 2 & EM-25/BSi-1 & 98.78 & 68.47 & 2670 & 1550 & 8.40 & 6.33 \\
\hline 3 & EM-30/BSi-1 & 93.83 & 71.14 & 3230 & 1530 & 14.30 & 5.67 \\
\hline 4 & EM-1/BSi-467 & 108.86 & 67.46 & 4683 & 1323 & 11.13 & 5.47 \\
\hline 5 & EM-3/BSi-467 & 97.35 & 65.92 & 3587 & 1003 & 10.30 & 5.67 \\
\hline 6 & EM-7/BSi-467 & 109.33 & 81.29 & 3890 & 1260 & 8.43 & 4.00 \\
\hline 7 & EM-8/BSi-467 & 90.22 & 76.30 & 3990 & 1547 & 5.47 & 4.13 \\
\hline 8 & EM-10/BSi-467 & 72.08 & 72.08 & 2230 & 1350 & 10.30 & 4.13 \\
\hline 9 & DM-2/ BSi-467 & 66.11 & 61.97 & 2730 & 1483 & 10.00 & 5.33 \\
\hline 10 & HYM-11/BSi-467 & 83.44 & 61.80 & 4047 & 1407 & 20.83 & 6.87 \\
\hline 11 & HYM-12/BSi-467 & 75.85 & 61.00 & 2217 & 1720 & 12.90 & 6.80 \\
\hline 12 & BSi-1 & 71.86 & 67.49 & 1957 & 1693 & 10.90 & 6.33 \\
\hline 13 & BSi-427 & 66.60 & 51.64 & 2520 & 1190 & 11.27 & 6.80 \\
\hline 14 & BSi-467 & 93.66 & 72.37 & 2337 & 1370 & 8.47 & 4.13 \\
\hline 15 & BSi-523 & 97.55 & 66.88 & 4083 & 1290 & 8.30 & 3.87 \\
\hline 16 & BSi-429 & 105.55 & 59.55 & 3767 & 1323 & 10.60 & 4.13 \\
\hline 17 & BSi-402 & 77.44 & 65.89 & 2253 & 1123 & 9.50 & 4.33 \\
\hline 18 & BSi-112 & 86.55 & 68.08 & 3610 & 1610 & 11.17 & 6.20 \\
\hline 19 & EM-15/BSi-467 & 88.75 & 70.09 & 1837 & 1573 & 9.17 & 5.30 \\
\hline 20 & Titas & 94.83 & 57.53 & 1827 & 1300 & 9.53 & 4.33 \\
\hline \multicolumn{2}{|c|}{ Mean } & 87.95 & 66.61 & 3052 & 1394 & 10.07 & 5.01 \\
\hline \multicolumn{2}{|c|}{ Max. } & 109.33 & 81.29 & 4083 & 1720 & 20.83 & 6.87 \\
\hline \multicolumn{2}{|c|}{ Min. } & 66.11 & 51.64 & 1827 & 1003 & 5.47 & 3.27 \\
\hline \multicolumn{2}{|l|}{ SD } & 13.41 & 1.50 & 885 & 43 & 3.75 & 1.11 \\
\hline
\end{tabular}

Table I. Plant height, dry matter accumulation and yield of millet under irrigated and rain fed condition 
under irrigated (Table I) and rainfed condition (Table II) were $94.83 \mathrm{~cm}$ and 57.53 respectively. An increase in plant height under irrigated was observed by Sarker et. al., 1989 and while Siddique et. al., 1999, observed a decrease in plant height due to drought. Fig.1 shows the relative plant height under rainfed condition as compared to plants grown under irrigated condition. The plant height stress index (PHSI) of var. Titas (Check variety) was 6.67. It is observed (Table I) that except lines, BSi-429 and Em-1/BSi-467, all the other lines showed higher PHSI than the test crop. Lines Em10/BSi-467, BSi-1 and DM-2/BSi-427 were less affected under drought in consideration of without irrigation or chemical fertilizer plant height. Data on plant height stress index (Table II, Fig.1) showed that most of the lines have better performance than the check variety Titas. Similar result was also reported by Blum and Ebercon (1981) in wheat. case of irrigated condition and it was reduced to $1310 \mathrm{mg} / \mathrm{plant}$ under rainfed condition (Table I). Incase of the check variety (Titas) total dry matter per plant was 1870 $\mathrm{mg}$ and $1300 \mathrm{mg}$ under irrigated (Table I) and rainfed (Table II) condition respectively. Total dry matter content is decreased under rainfed condition as compared to irrigated condition (Table I ). The dry matter stress index of Titas was 71.15 (Table II). Only few lines like EM-151/BSi-467 and BSi-1 showed better performance out of 19 lines as compared to control (Table II and Fig 2). A decrease in dry matter production under rain fed condition is also observed by Bunting and Kassam (1988) and El Nadi (1969). An increase in dry matter of Brassica under irrigated condition was observed by Clarke and Simpson (1978). Considering dry matter stress index (DMSI), (Table III) relative dry matter

Table II. Plant height stress index (PHSI), Dry matter stress index (DMSI) and yield stability ratio (YS), Stress tolerance (TOL) and Yield stability ratio (YSI) of millet. (Lines with * indicate superior against drought)

\begin{tabular}{llccccc}
\hline Sl.No. & Lines/varieties & PHSI (\%) & DMSI (\%) & YS (\%) & TOL & YSI \\
\hline 1 & EM-6/BSi-1 & 82.00 & 34.86 & 39.73 & 4.96 & 0.40 \\
2 & EM-25/BSi-1 & 69.32 & 58.05 & 75.36 & 2.01 & 0.750 \\
3 & EM-30/BSi-1 & 75.12 & 47.37 & 39.65 & 8.63 & 0.396 \\
4 & EM-1/BSi-467 & 61.97 & 28.25 & 49.15 & 5.66 & 0.490 \\
5 & EM-3/BSi-467 & 67.71 & 27.98 & 55.05 & 4.63 & 0.550 \\
6 & EM-7/BSi-467 & 74.35 & 32.39 & 47.45 & 4.43 & 0.470 \\
7 & *EM-8/BSi-467 & 84.57 & 38.77 & 75.50 & 1.34 & 0.755 \\
8 & EM-10/BSi-467 & 95.16 & 60.54 & 40.09 & 6.17 & 0.400 \\
9 & DM-2/ BSi-467 & 93.74 & 54.32 & 53.30 & 4.67 & 0.530 \\
10 & HYM-11/BSi-467 & 74.07 & 34.77 & 32.98 & 13.96 & 0.329 \\
11 & HYM-12/BSi-467 & 80.42 & 77.58 & 52.71 & 6.10 & 0.527 \\
12 & $*$ BSi-1 & 93.92 & 86.51 & 58.07 & 4.57 & 0.581 \\
13 & BSi-427 & 77.53 & 47.04 & 60.34 & 4.47 & 0.603 \\
14 & BSi-467 & 77.27 & 58.62 & 48.76 & 4.34 & 0.488 \\
15 & BSi-523 & 68.56 & 25.38 & 46.62 & 4.43 & 0.466 \\
16 & BSi-429 & 56.60 & 35.12 & 38.96 & 6.47 & 0.390 \\
17 & BSi-402 & 85.09 & 49.84 & 45.58 & 5.17 & 0.456 \\
18 & $*$ BSi-112 & 78.66 & 44.60 & 55.51 & 4.97 & 0.555 \\
19 & $*$ EM-15/BSi-467 & 78.97 & 85.63 & 57.80 & 3.87 & 0.578 \\
20 & Titas & 60.67 & 71.15 & 45.39 & 5.20 & 0.454 \\
\hline
\end{tabular}

The dry matter accumulation of millet increased up to 110 days after emergence in all the cultivars under both irrigated and rainfed condition (Table I). All the lines including the check variety showed a decrease in dry matter accumulation under rainfed condition as compared to that of under irrigated condition. The mean dry weight was $3052 \mathrm{mg} / \mathrm{plant}$ in stress index (Fig. 4) as compared to test crop (Titas), lines HYM/11/BSi-427, HYM 12/BSi-427, EM 15/BSi-467 and BSi-1 showed better growth.

In general millet shows a better yield under irrigated than that of under rainfed condition (Table I). The mean yield 


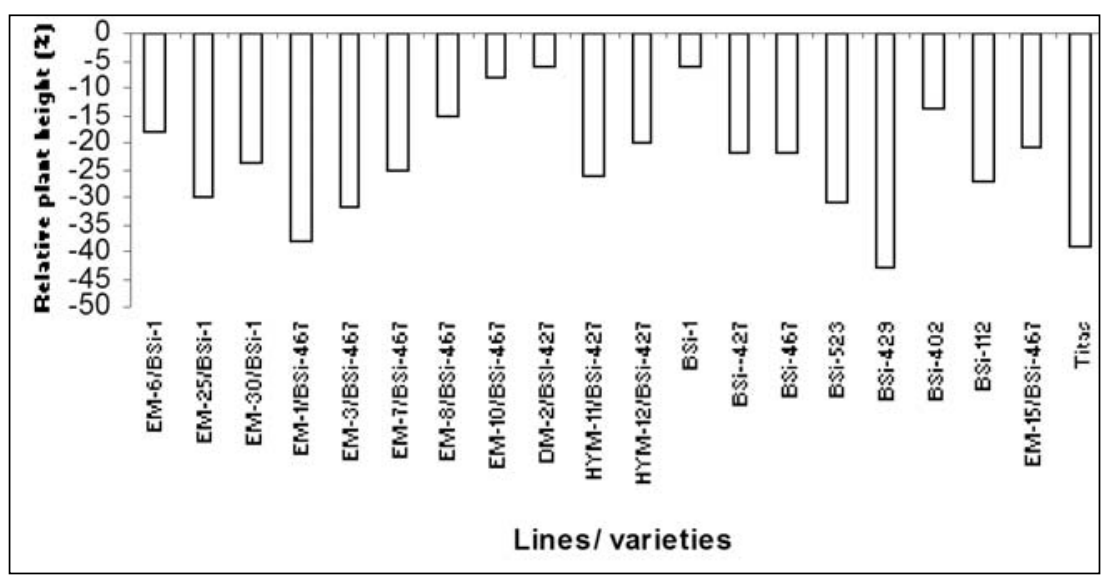

Fig. 1. Relative plant height as compared to control (irrigated)

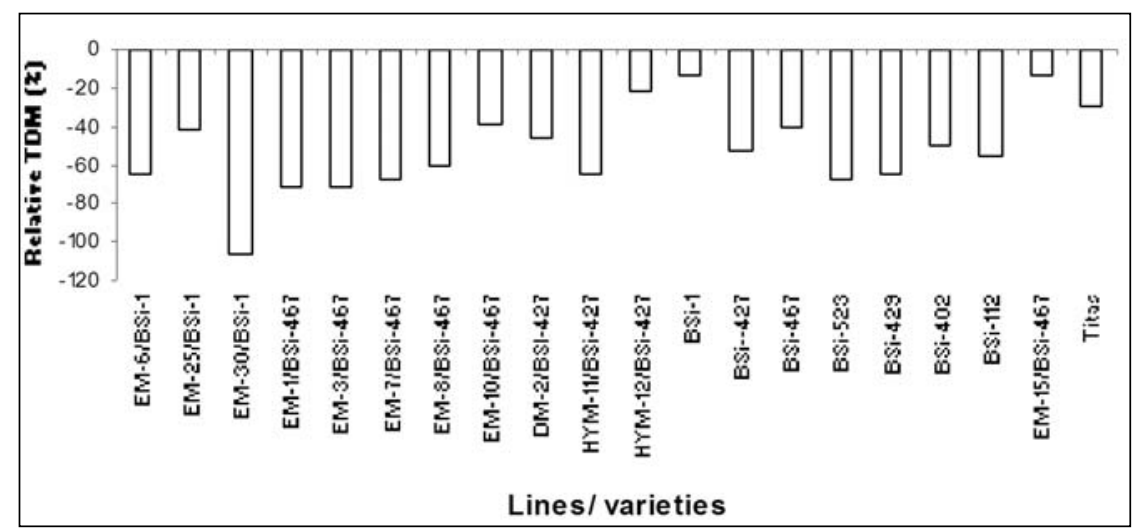

Fig. 2. Relative total dry matter accumulation as compared to control (irrigated)

(g/plant) was $10.07 \mathrm{~g}$ in case of irrigated (Table I) and $5.01 \mathrm{~g}$ in case of rainfed condition (Table II). In case of Titas, the yield under irrigated condition was 9.54 and $4.33 \mathrm{~g}$ under rainfed condition. As observed in the present study, about two times higher yield was obtained under irrigated than under moisture stress. It is observed from Table II, that when TOL value is higher, the yield reduction is also higher. The highest TOL value was observed in HYM-12/BSi-467 i.e. it shows the highest drought sensitivity. Lower TOL value was observed in EM-25/BSi-1 and EM-8/BSi-467 and these two lines performed better than the check variety. Considering yield as compared to control (Irrigated), the mean yield /plant is decreased from $10.07 \mathrm{~g}$. to $5.01 \mathrm{~g}$.(Table I and II). Lines BSi 421, EM 30/ BSi 1, EM 25/ BSi 1, EM 8/ BSi- 461 showed better performance than the test crop (Titas) when yield is compared. Lower value is the selection criteria for YSI. Drought susceptibility index was less than one for all the genotypes. Clarke et al. (1984 suggested that) tolerant genotyppes have DSI less than one. All the genotypes showed YSI less than one including Titas (test crop). Most of the genotypes showed better YSI than the test crop.

Stress intensity of millet was 49.75 under drought stress condition. This indicates that yield of millet decreased by $49.75 \%$ under drought condition.

Clarke and Simpson (1978), observed a higher seed yield of Brassica napus under irrigated condition than that of under rainfed condition. According to Mathur and Tomar (1972), irrigation increased seed yield. More than double yield was observed in case of rape under irrigated condition compared to crops grown under rainfed condition (Krogman and Hobbs, 1975).Millet gave better yield under irrigated condition by promoting greater plant growth and more seeds per plant than when irrigation was not applied (Table I). Table II also shows that in case of Titas, the yield stability ratio was 45.34 in Titas (Table II, Fig. 3). Nine lines out of 19 showed better yield stability ratio as compared to test crop (Titas). 
Table III. Soil moisture percentage during millet growing period

\begin{tabular}{|c|c|c|c|c|c|c|}
\hline \multirow[t]{3}{*}{ Date of sampling } & \multicolumn{3}{|c|}{ Irrigated } & \multicolumn{3}{|c|}{ Rainfed } \\
\hline & \multicolumn{3}{|c|}{ Dept of the soil $(\mathrm{cm})$} & \multicolumn{3}{|c|}{ Dept of the soil (CM) } \\
\hline & $0-15$ & $\begin{array}{l}15-30 \\
\end{array}$ & $30-45$ & $0-15$ & $15-30$ & $30-45$ \\
\hline $9-12-07$ & 14.45 & 18.75 & 23.32 & 14.45 & 18.75 & 23.32 \\
\hline $13-1-08$ & 13.98 & 17.20 & 20.39 & 9.25 & 16.53 & 18.63 \\
\hline $14-2-08$ & 17.38 & 19.27 & 19.27 & 15.49 & 17.97 & 18.96 \\
\hline $23-2-08$ & 15.81 & 17.91 & 21.62 & 12.9 & 16.92 & 19.25 \\
\hline $22-3-08$ & 14.49 & 17.53 & 19.63 & 12.02 & 15.6 & 13.44 \\
\hline $02-4-08$ & 10.18 & 16.41 & 18.19 & 9.20 & 13.44 & 15.21 \\
\hline
\end{tabular}

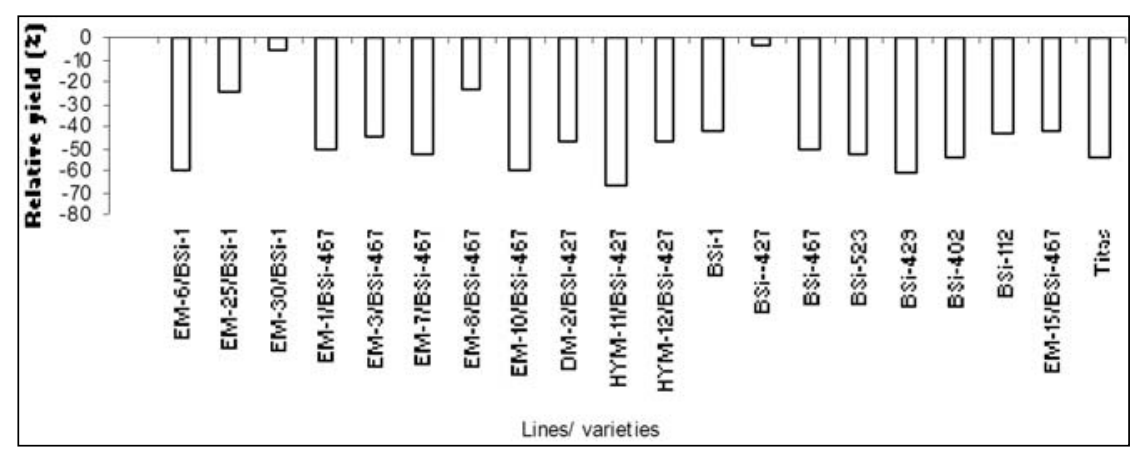

Fig. 3. Relative yield as compared to control (irrigated)

Considering all the parameters, like PHSI, DMSI and YS ratio, TOL only three lines BSi-1, EM 15/BSi 467 and HYM-12/ BSi 427 shows better performances than the check variety Titas. These three lines could be selected for further trial in the drought prone areas of Bangladesh..

\section{References}

Bauslama M and Schapough. (1984), Stress tolerance in soybean.I. Evaluation of the screening technique for heat and drought. Crop Sci. 24: 933-937.

BBS. (2000), Yearbook of Agricultural Statistics of Bangladesh, Statistic Division, Ministry of Planning, Dhaka, Bangladesh.

Blum A and Ebercon A (1981), Cell membrane stability as a measure of drought and heat tolerance in wheat. Crop Sci. 21: 43-47.

Bunting, AH and Kassam AH (1988), Principles of crop water use, dry matter production and dry matter parti- tioning that govern choices of crops and systems. pp. 43-61. In Bidinger and C. Johansen (Eds.). Drought Research Priorities for the dry land tropics. ICRISAT, Patancheru, India.

Clarke JM and Simpson SM (1978), Influence of irrigation and seedling rate on yield and yield components of Brassica napus cv. Tower Can. J. Sci. 58: 731-734.

El Nadi AH (1969), Water relations of beans. I. Effect of water stress on growth and flowering. Expt. Agril. 5: 195-207.

Hossain ABS, Sears AG, Cox TS and Paulsen GM (1990), Desiccation tolerance and its relationship to assimilate partitioning in winter wheat. Crop Sci., 30: 622-627.

Hisao TC (1973), Plant response to water stress. Ann. Rev. Plant Physiol. 24: 519-570. 
Krogman KK and Hobbs EH (1975), Yield and morphological response of rape (Brassica campestries L. cv. Span) to irrigation and fertilizer treatments. Can. J. Plant Sci. 55: 903-909.

Lewis EB (1954), Gene environment interaction. Heredity. 8: $333-356$.

Mathur OPPS Tomar. (1972), Irrigation requirement of Rye (Brassica juncea) crop in western Rajsthan. Indian $J$. Agron. 17: 306-308.
Sarker MAR, Ahsan MR, Sarker AV and Hossain SMA (19890), Effect of nitrogen and irrigation at different growth stages of mustard. Bangladesh J. Agril. Sci. 16: 283-288.

Siddique MRB, Hamid A and Islam MS (1999), Drought stress effect on phenological character of wheat. Bangladesh J. Agril. Sci. 24: 255-263.

Received: 10 April 2012; Revised: 27 June 2013; Accepted: 17 December 2013. 